International Journal of Environmental Research and

Public Health

ISSN 1660-4601

www.mdpi.com/journal/ijerph

Article

\title{
Metabolic Polymorphisms and Clinical Findings Related to Benzene Poisoning Detected in Exposed Brazilian Gas-Station Workers
}

\section{Simone Mitri ${ }^{1, *}$, Antônio Sérgio Almeida Fonseca ${ }^{2}$,Ubirani Barros Otero ${ }^{3}$, Marianne Medeiros Tabalipa ${ }^{3}$, Josino Costa Moreira ${ }^{1}$ and Paula de Novaes Sarcinelli ${ }^{1}$}

1 Toxicology Laboratory, Center for Studies of Worker's Health and Human Ecology, Oswaldo Cruz Foundation, Rio de Janeiro 21041-210, Brazil; E-Mails: josinocm@fiocruz.br (J.C.M.); paula@ensp.fiocruz.br (P.N.S.)

2 Medical Ambulatory, Center for Studies of Worker's Health and Human Ecology, Oswaldo Cruz Foundation, Rio de Janeiro 21041-210, Brazil; E-Mail: antoniosergio@ensp.fiocruz.br

3 Technical Unit of Occupational Exposure, Environmental and Cancer, Prevention and Surveillance Coordination, National Cancer Institute, Rio de Janeiro 20230-130, Brazil;

E-Mails: uotero@inca.gov.br (U.B.O.); mtabalipa@yahoo.com (M.M.T.)

* Author to whom correspondence should be addressed; E-Mail: simitri@ensp.fiocruz.br.

Academic Editor: Paul B. Tchounwou

Received: 10 June 2015 / Accepted: 14 July 2015 / Published: 21 July 2015

\begin{abstract}
Benzene is a ubiquitous environmental pollutant and an important industrial chemical present in both gasoline and motor vehicle emissions. Occupational human exposure to benzene occurs in the petrochemical and petroleum refining industries as well as in gas-station workers, where it can lead to benzene poisoning (BP), but the mechanisms of BP are not completely understood. In Brazil, a significant number of gas-station service workers are employed. The aim of the present study was to evaluate alterations related to $\mathrm{BP}$ and metabolic polymorphisms in gas-station service workers exposed to benzene in the city of Rio de Janeiro, Brazil. Occupational exposure was based on clinical findings related to $\mathrm{BP}$, and metabolic polymorphisms in 114 Brazilian gas-station attendants. These workers were divided into No Clinical Findings (NCF) and Clinical Findings (CF) groups. Neutrophil and Mean Corpuscular Volume (MCV) showed a significant difference between the two study groups, and neutrophil has the greatest impact on the alterations suggestive of BP. The clinical findings revealed higher frequencies of symptoms in the CF
\end{abstract}


group, although not all members presented statistical significance. The frequencies of alleles related to risk were higher in the CF group for GSTM1, GSTT1, CYP2E1 7632T > A, but lower for NQO1 and CYP2E1 1053C > T genotypes. Moreover, an association was found between GSTM1 null and alterations related to BP, but we did not observe any effects of other polymorphisms. Variations in benzene metabolizing genes may modify benzene toxicity and should be taken into consideration during risk assessment evaluations.

Keywords: occupational health; benzene poisoning; gas station worker; genetic polymorphisms; benzene metabolism

\section{Introduction}

Benzene is a ubiquitous environmental pollutant, and an important industrial chemical [1,2]. Exposure to it can cause various health hazards and contributes to increasing the risk of blood and bone marrow disorders, including hematotoxicity, genotoxicity and leukemia, even in workers exposed to low levels in the air [3-7]. Exposure to benzene can be environmental or occupational. Benzene is a component of crude oil, cigarette smoke and gasoline [8-11]. Occupational human exposure to benzene occurs in the petrochemical and petroleum refining industries, as well as from exposure to gasoline and automobile exhaust, so employees of gas-stations are constantly occupationally exposed to higher benzene concentrations and for longer time periods than people driving cars and the general population. In addition, these workers are also exposed to other toxicsubstances present in gasoline, such as toluene, ethylbenzene and xylene [12,13]. This occupation employs a significant number of workers in Brazil, a total of 184,733 distributed over 39,450 gas stations across the country (data of 2010) [14].

Occupational exposure to benzene frequently leads to benzene poisoning (BP), and there is an accepted set of signs, symptoms and complications, among which impaired bone marrow is the most important one. The most frequent signs and symptoms are asthenia, myalgia, drowsiness, dizziness and repeated infections, and the most relevant hematological data are neutropenia, leukcopenia, eosinophilia, lymphopenia, monocytopenia, macrocytosis, basophilic stippling, pseudo Pelger and thrombocytopenia [15-17]. The mechanisms of BP are not completely understood, but it is generally accepted that it is mediated by a series of benzene activation and detoxification enzymes, which can be modified by genetic variation [18-20]. Several genes of benzene metabolism responsible for its activating and detoxifying have polymorphic variants, which may alter its exposure risk [21-24]. Thus, polymorphism of cytochrome P450 2E1 (CYP2E1), myeloperoxidase (MPO), NAD(P)H: quinoneoxidoreductase 1 (NQO1), glutathione S-transferase theta 1 (GSTT1), and glutathione S-transferase mu 1 (GSTM1), which are involved in benzene activation and detoxification, may affect individual susceptibility to benzene toxicity[20,25-34]. In the current study, we evaluated alterations related to BP and metabolic polymorphisms in gas station attendants exposed to benzene in the city of Rio de Janeiro, Brazil. 


\section{Material and Methods}

\subsection{Chemicals and Suppliers}

Taq DNA polymerase, Taq buffer and $\mathrm{MgCl}_{2}$, dNTPs, and digestion enzymes were purchased from Thermo Scientific, (EU) Lithuania. Primers, ladders, and agarose were obtained from Invitrogen by Life Technologies, CA, USA. The Gelred ${ }^{\mathrm{TM}}$ staining was supplied by Biotium, Inc., Hayward, CA, USA. Proteinase K was obtained from Roche Diagnostic, Mannheim, Germany.

\subsection{Study Population and Collection of Samples}

A total of 114 workers from seven gas stations in the city of Rio de Janeiro, Brazil, were enrolled in a cross-sectional study. The study was open to participation by male and female workers over 18 years of age. The study was approved by the ethical committee of the Sergio Arouca National School of Public Health (ENSP), Oswaldo Cruz Foundation, number CAAE 0021.0.031.000-10, and all participants signed an informed consent form. The participating workers were interviewed by trained personnel, and a questionnaire was used to obtain general information, including demographic characteristics, cigarette smoking, alcohol consumption, medical history, and occupational data. A blood sample of about $5 \mathrm{mLwas}$ collected from each study participant, and these were stored under refrigeration until analysis.

\subsection{Evaluation of Clinical Alterations Related to Benzene Poisoning}

Clinical evaluations were performed at the Center for Studies of Worker Health and Human Ecology (CESTEH) and the National Cancer Institute (INCA), based on the Evaluation Protocols of Health Workers Exposed to Benzene [17,35]. All participants underwent physical and hematological examination.

Hematological indices such as white blood cell (WBC), erythrocytes, hematocrit, and neutrophil counts were evaluated at INCA. Additionally, data on somatic symptoms were collected from all participants. The interpretation of these data was carried out by physicians from CESTEH. The studied population was categorized into two groups based on clinical findings suggestive of benzene poisoning.

\subsection{Genotyping}

Genotyping was conducted at the Toxicology Laboratory of CESTEH. Genomic DNA was extracted from whole blood samples by the salting-out method. Polymerase Chain Reaction-Restricted Fragment Length Polymorphism (PCR-RFLP) techniques were applied to amplify the polymorphic fragments of CYP2E1 1053C > T and CYP2E1 7632T > A, NQO1 609C > T and MPO 463G > A. Multiplex PCR was done for GSTM1 and GSTT1 deletion polymorphisms, and beta-globin gene was used in the same system as a control. The PCR was done using 50-200 ng of genomic DNA, $0.4 \mu \mathrm{M}$ of each primer, $1 \times$ PCR buffer, $250 \mu \mathrm{M}$ of dNTPs, $1.5 \mathrm{mM}$ of $\mathrm{MgCl}_{2}$ and $1-2.5$ units of Taq polymerase in a $50 \mu \mathrm{L}$ reaction volume. Table 1 shows primers sequences and PCR and digestion conditions for each polymorphism. The resulting products of PCR and digestion were separated on $2-3 \%$ agarose gels by electrophoresis and visualized with GelRed ${ }^{\mathrm{TM}}$ (Biotium) Nucleic Acid Gel staining and ultraviolet transilluminator. All genotypes were evaluated and independently confirmed 
by at least two people. A total of $10 \%$ of DNA samples were selected randomly for repeat analyses in order to verify the accuracy of the method, and the concordance rate was $100 \%$.

Table 1. Primer sequences, amplification and digestion conditions used in the study.

\begin{tabular}{|c|c|c|c|c|}
\hline Polymorphisms & Primer sequences & PCR & Digestion & $\begin{array}{c}\text { PCR and } \\
\text { restrictionpatterns } \\
\text { (bp) } \\
\end{array}$ \\
\hline $\begin{array}{l}\text { CYP2E1 } \\
1053 \mathrm{C}>\mathrm{T}\end{array}$ & $\begin{array}{l}\text { F: 5'-CCAGTCGAGTCTACATTGTCA-3' } \\
\text { R: 5'-TTCATTCTGTCTTCTAACTGG-3' }\end{array}$ & $\begin{array}{l}35 \text { cycles: } 95^{\circ} \mathrm{C} \\
\text { for } 1 \mathrm{~min}, 60^{\circ} \mathrm{C} \\
\text { for } 1 \mathrm{~min} \text {, and } \\
72^{\circ} \mathrm{C} \text { for } 1 \mathrm{~min}\end{array}$ & $\begin{array}{c}\text { RsaI, } \\
\text { overnight } \\
\text { at } 37^{\circ} \mathrm{C}\end{array}$ & $\begin{array}{c}\text { PCR: } 410 \\
\text { CC: } 360,50 \\
\text { CT: } 410,360,50 \\
\text { TT: } 410\end{array}$ \\
\hline $\begin{array}{l}\text { CYP2E1 } \\
7632 \mathrm{~T}>\mathrm{A}\end{array}$ & $\begin{array}{l}\text { F: 5'-TCGTCAGTTCCTGAAAGCAGG-3' } \\
\text { R: 5'-GAGCTCTGATGCAAGTATCGCA-3'. }\end{array}$ & $\begin{array}{l}35 \text { cycles: } 94{ }^{\circ} \mathrm{C} \\
\text { for } 30 \mathrm{~s} ; 63^{\circ} \mathrm{C} \\
\text { for } 30 \mathrm{~s} ; 72^{\circ} \mathrm{C} \\
\text { for } 1 \mathrm{~min}\end{array}$ & $\begin{array}{c}\text { DraI, } \\
3-5 \mathrm{~h} \text { at } \\
37^{\circ} \mathrm{C}\end{array}$ & $\begin{array}{c}\text { PCR: } 375 \\
\text { TT: } 375 \\
\text { TA: } 375,249,126 \\
\text { AA: } 249,126\end{array}$ \\
\hline $\begin{array}{l}\mathrm{NQO1} \\
609 \mathrm{C}>\mathrm{T}\end{array}$ & $\begin{array}{l}\text { F: 5'-GAGACGCTAGCTCTGAACTGAT-3' } \\
\text { R: 5'-ATTTGAATTCGGGCGTCTGCTG-3' }\end{array}$ & $\begin{array}{l}30 \text { cycles: } 94^{\circ} \mathrm{C} \\
\text { for } 10 \mathrm{~s} ; 57^{\circ} \mathrm{C} \\
\text { for } 20 \mathrm{~s} ; 72^{\circ} \mathrm{C} \\
\text { for } 45 \mathrm{~s}\end{array}$ & $\begin{array}{c}\text { Hinfl, } \\
\text { overnight } \\
\text { at } 37^{\circ} \mathrm{C}\end{array}$ & $\begin{array}{c}\text { PCR: } 304 \\
\text { CC: } 271 \\
\text { CT: } 151,120 \\
\text { TT: } 271,151,120\end{array}$ \\
\hline $\begin{array}{c}\text { MPO } \\
463 \mathrm{G}>\mathrm{A}\end{array}$ & $\begin{array}{c}\text { F: 5'-CGGTATAGGCACACAATGGTGAG-3' } \\
\text { R: 5'-GCAATGGTTCAAGCGATTCTT-3' }\end{array}$ & $\begin{array}{l}35 \text { cycles: } 91^{\circ} \mathrm{C} \\
\text { for } 1 \mathrm{~min} ; 59^{\circ} \mathrm{C} \\
\text { for } 1 \mathrm{~min} ; 71^{\circ} \mathrm{C} \\
\text { for } 1 \mathrm{~min}\end{array}$ & $\begin{array}{l}\text { AciI, } 3 \mathrm{~h} \\
\text { at } 37{ }^{\circ} \mathrm{C}\end{array}$ & $\begin{array}{c}\text { PCR: } 350 \\
\text { GG: } 169,120,61 \\
\text { GA: } 289,169,120 \text {, } \\
61 \\
\text { AA: } 289,61\end{array}$ \\
\hline GSTM1 & $\begin{array}{l}\text { F: 5'-GAACTCCCTGAAAAGCTAAAGC-3' } \\
\text { R: 5'-GTTGGGCTCAAATATACGGTG-3' }\end{array}$ & $\begin{array}{l}35 \text { cycles: } 94{ }^{\circ} \mathrm{C} \\
\text { for } 2 \mathrm{~min} ; 61{ }^{\circ} \mathrm{C} \\
\text { for } 1 \mathrm{~min} ; 72^{\circ} \mathrm{C} \\
\text { for } 2 \mathrm{~min}\end{array}$ & & PCR: 215 \\
\hline GSTT1 & $\begin{array}{l}\text { F: 5'-TTCCTTACTGGTCCTCACATCTC-3' } \\
\text { R: 5'-TCACCGGATCATGGCCAGCA-3' }\end{array}$ & $\begin{array}{l}\text { for } 2 \mathrm{~min} ; 61{ }^{\circ} \mathrm{C} \\
\text { for } 1 \mathrm{~min} ; 72 \\
{ }^{\circ} \mathrm{CC} \text { for } 2 \mathrm{~min}\end{array}$ & & PCR: 480 \\
\hline$\beta$-globin & $\begin{array}{l}\text { F: 5'-CAACTTCATCCACGTTCACC-3' } \\
\text { R: 5'-GAAGAGCCAAGGACAGGTAC-3' }\end{array}$ & $\begin{array}{c}35 \text { cycles: } 94 \\
{ }^{\circ} \mathrm{C} \text { for } 2 \mathrm{~min} ; 61 \\
{ }^{\circ} \mathrm{C} \text { for } 1 \mathrm{~min} ; 72 \\
{ }^{\circ} \mathrm{C} \text { for } 2 \mathrm{~min}\end{array}$ & & PCR: 268 \\
\hline
\end{tabular}

\subsection{Statistical Analysis}

Statistical analysis was carried out using the SPSS statistical software package 17.0. (Chicago, IL, USA). The normality of the distributions was assessed in accordance with the Kolmogorov-Smirnov test. The t-test, $\chi 2$-test and the Mann-Whitney U-test were used to analyze 
differences between the groups. The relationships between several variables, mainly genetic polymorphisms with BP were verified by Spearman correlation analysis. The impacts of genotypes and other analyzed variables on BP were tested using multivariate logistic regression. Deviation from Hardy-Weinberg equilibrium was assessed by a $\chi 2$-test. The significance level for all tests was $p \leq 0.05$.

\section{Results}

\subsection{Clinical Evaluation and Characteristics of the Studied Population}

In accordance with the presence of clinical and laboratory changes that can evolve into BP and with alterations suggestive of BP, subjects were divided into two groups: No Clinical Findings (NCF) and Clinical Findings $(\mathrm{CF})$. From a total of 114 workers, $63.2 \%(\mathrm{n}=72)$ were classified into the CF group, and about $80 \%$ of them were male, as shown in Table 2 . This table has other information about the workers, such as their basic demographic and occupational characteristics.

Table 2. Demographic and occupational characteristics of the study population (114 subjects).

\begin{tabular}{|c|c|c|}
\hline Variables & NCF (n= 42) & CF (n= 72) \\
$\mathbf{n}(\mathbf{\%}) \mathbf{( \% )}$
\end{tabular}


Table 2.Cont.

\begin{tabular}{|c|c|c|}
\hline Variables & $\begin{array}{c}\text { NCF (n= 42) } \\
\mathbf{n}(\mathbf{\%}) \mathbf{~}\end{array}$ & $\begin{array}{c}\text { CF (n = 72) } \\
\mathbf{n}(\mathbf{\%})\end{array}$ \\
\hline Smoking consumption & $10(24,4)$ & $13(18,3)$ \\
Yes & $31(75,6)$ & $58(81,7)$ \\
No & & \\
& & $55(77.5)$ \\
Alcohol consumption & $27(65.9)$ & $16(22.2)$ \\
Yes & $14(34.1)$ & \\
No & & $15.2 \pm 1.38$ \\
Exposure duration (years) & $13 \pm 1.97$ & - \\
Mean & - & 52 \\
Min & 42 & \\
Max &
\end{tabular}

The data presented in Table 3 represent the differences in hematological indices between the groups. The CF group showed lower values than NCF, except to lymphocytes and Mean corpuscular volume (MCV). We found an association between neutrophil and $\mathrm{BP}(\mathrm{OR}=1.130,95 \% \mathrm{CI}=1.035-1.234)$.

Table 3. Hematological values observed in NCF and CF.

\begin{tabular}{cccc}
\hline Variables & $\begin{array}{c}\text { NCF } \\
\text { Mean } \pm \text { SD }\end{array}$ & $\begin{array}{c}\text { CF } \\
\text { Mean } \pm \text { SD }\end{array}$ & p-value \\
\hline Red Blood Cell (million/mL) & $4.90( \pm 0.3318)$ & $4.77( \pm 0.5513)$ & 0.139 \\
Hemoglobin(g/dL) & $14.02( \pm 1.195)$ & $14.00( \pm 1.698)$ & 0.940 \\
Hematocrit (\%) & $41.33( \pm 3.070)$ & $41.00( \pm 4.595)$ & 0.673 \\
MCV (fL) & $84.49 \pm 0.63$ & $86.13 \pm 0.80$ & 0.005 \\
WBC (cells/ $\mu \mathrm{L})$ & $7,830( \pm 2,115)$ & $7,260( \pm 1,628)$ & 0.125 \\
Neutrophil $(\%)$ & $58.53( \pm 5.883)$ & $53.97( \pm 9.537)$ & 0.003 \\
Lymphocyte $(\%)$ & $30.93( \pm 5.555)$ & $34.20( \pm 8.757)$ & 0.019 \\
Platelet (billion/L) & $252.10( \pm 57.901)$ & $243.52( \pm 63.108)$ & 0.487 \\
\hline
\end{tabular}

The principal somatic symptoms reported by the subjects are illustrated in Figure 1.The graph shows that the CF group recorded higher frequencies of headaches $(80 \% v s .20 \%$; $p=0.023)$, muscle cramps (84.6\% vs. 15.4\%; $p=0.009)$, tingling $(77.8 \%$ vs. $22.2 \% ; p=0.161)$, drowsiness (76.9\% vs. 23.1\%; $p=0.243)$, dizziness (75\% vs. $25 \%$; $p=0.369)$, weight loss $(90 \%$ vs. $10 \%$; borderline $p=0.065)$, and recurrent infections $(0 v s .100 \% ; p=0.037)$. 


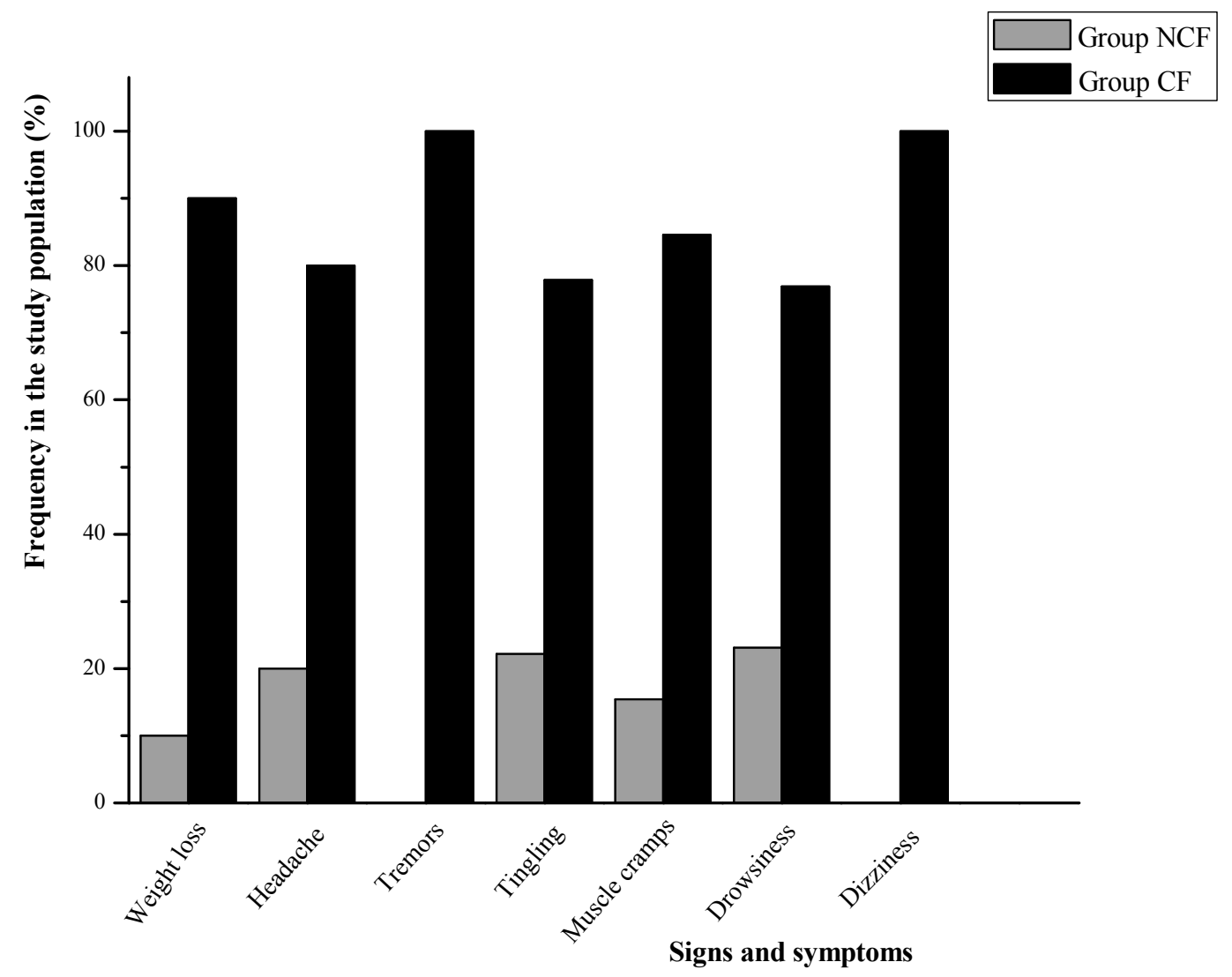

Figure 1. Comparison of somatic symptoms of BP between groups ( $* \mathrm{SD}$, weight loss: \pm 0.15 (NCF) and \pm 0.33 (CF); headache: \pm 0.47 (NCF) and \pm 0.49 (CF); tremors: \pm 1.39 (NCF) and \pm 0.26 (CF); tingling: muscle cramps: $\pm 0.28(\mathrm{NCF})$ and $\pm 0.47(\mathrm{CF})$; drowsiness: $\pm 0.40(\mathrm{NCF})$ and $\pm 0.35(\mathrm{CF})$; dizziness: $\pm 0.26(\mathrm{NCF})$ and $\pm 0.33(\mathrm{CF})$.

\subsection{Genetic Analysis}

The following genotype frequencies of each polymorphism in the population were found: GSTM1-68.7\% (positive) and 31.3\% (null); GSTT1-75.8\% (positive) and 24.2\% (null); NQO1-64.1\% (TC), 30.4\% (TC), 5.4\% (TT); MPO-43.2\% (GG), 49.5\% (GA), 7.4\% (AA); CYP2E1 RsaI-77\% (CC), 13.8\% (CT), 9.2\% (TT) and; CYP2E1 DraI-82.1\% (TT), 16.8\% (TA), and 1.1\% (AA).

The variant allele frequencies among $\mathrm{NCF}$ and $\mathrm{CF}$ groups are summarized in Table 4 . The $\mathrm{CF}$ group presented higher frequencies of variant for CYP2E1 7632T > A; null alleles for GSTM1 and GSTT1. However, although there were lower frequencies for NQO1 and CYP2E1 1053C $>$ T than in the NCF group, there was no statistical difference between them. For GSTM1, the frequency null genotype was 0.26 and 0.34 for the NCF and the CF groups, respectively. In regard to the GSTT1 gene, the groups presented frequencies of $0.20(\mathrm{NCF})$ and $0.26(\mathrm{CF})$. The $\mathrm{T}$ allele of CYP2E1 1053C $>\mathrm{T}$ showed 0.21 (14.3\% homozygous and 14.3\% heterozygous) and 0.14 (6.8\% homozygous and 13.6\% heterozygous) for NCF and CF, respectively. For CYP2E1 7632T > A were found 0.06 (12.1\% of heterozygous and no one homozygous) in NCF, and 0.11 (19.4\% heterozygous and $1.6 \%$ homozygous) in CF. NQO1 showed 0.32 (38.7\% of heterozygous and $6.5 \%$ of homozygous) in NCF and 0.18 (26.2\% heterozygous and $4.9 \%$ homozygous) in CF. MPO polymorphism, whose variant allele is not 
related to susceptibility but to protection, presented 0.30 (48.5\% heterozygous and $9.1 \%$ homozygous) in NCF, and 0.31 (50\% heterozygous and $6.5 \%$ homozygous) in CF group. The genotype distributions were in accordance with Hardy-Weinberg, except for GSTM1,GSTT1 and CYP2E1 1053C > T.

Table 4. Variant allele frequencies in NCF and CF.

\begin{tabular}{ccccc}
\hline Polymorphisms & Variant allele & NCF & CF & p-value \\
\hline NQO1 & $\mathrm{T}^{\mathrm{a}}$ & 0.32 & 0.18 & 0.233 \\
CYP2E1 1053C $>$ T & $\mathrm{C}^{\mathrm{a}}$ & 0.21 & 0.14 & 0.394 \\
CYP2E17632T $>$ A & $\mathrm{A}^{\mathrm{a}}$ & 0.06 & 0.11 & 0.284 \\
GSTM1 & null $^{\mathrm{a}}$ & 0.26 & 0.34 & 0.452 \\
GSTT1 & null $^{\mathrm{a}}$ & 0.20 & 0.26 & 0.539 \\
MPO & $\mathrm{A}^{\mathrm{b}}$ & 0.30 & 0.31 & 0.639 \\
\hline
\end{tabular}

${ }^{\mathrm{a}}$ alleles related to risk; ${ }^{\mathrm{b}}$ alleles related to protection.

According to the literature, the alleles presented in Table 4 are related to benzene exposure and its effects on health $[4,19,21,22,28,29]$. The number of alleles related to risk showed associations with the presence of clinical findings of BP (Spearman Chi-Square $=0.196 ; p$-value $=0.024)$. Logistic regression showed that GSTM1 null genotype had an impact on the changes related to BP $(\mathrm{OR}=5.131,95 \% \mathrm{CI}=1.137-23.151)$. No significant influence of the other polymorphisms was observed in the changes related to BP (results not shown).

\section{Discussion}

We evaluated alterations related to $\mathrm{BP}$ and benzene metabolic polymorphisms in gas-station workers in Rio de Janeiro, Brazil since this professional category has been occupationally exposed to benzene. Studies have shown that gas-station service workers are exposed to levels of tens to hundreds of ppb [14,36,37]. However, there have been few studies carried out of individual genetic susceptibility in gas-station workers.

In the present study, most of the workers showed clinical and laboratory changes that can evolve into BP, 63.2\%. Diagnosis of BP from occupational exposure is predominantly clinical and epidemiological, based on medical history, laboratory data and clinical symptoms [17]. BP is considered when the individual presents a set of signs and symptoms after exposure to benzene. Common symptoms are asthenia, headache, myalgia, drowsiness, dizziness, tremor and recurrent infections [15,16,38], and the most relevant hematological data are a decrease in blood cells and macrocytosis[39,16,40,41].

We found that although the difference was not significant, the CF group showed a reduced blood cell count in comparison with the NCF one. Neutrophil and MCV (indicative of macrocytosis) showed a significant difference between groups, and the percentage of neutrophil was the hematological variable with the greatest impact on the alterations suggestive of BP. These results were consistent with preview studies. The study of Quet al. (2002) [42] observed a decrease in red and white cell counts, especially neutrophils, in Chinese workers exposed to benzene. Lan et al. (2004) [4] also found a decrease in almost all blood cells in an occupationally exposed population, which highlights that the broad action of benzene on various subtypes of blood cells seems to provide strong evidence of its toxicity in the progenitor cells of the bone marrow cells. 
In relation to symptoms, we observed higher frequencies of headaches, recurrent infections, muscle cramps, tingling, drowsiness, dizziness and weight loss in the CF group, although not all with statistical significance. D'Alascio et al. (2014) [38] reported similar symptoms in Brazilian gas-station workers with a higher prevalence of fatigue, headache, tremor, insomnia, and drowsiness.

Six polymorphisms in benzene metabolizing genes were analyzed to verify the presence of genetic susceptibility in these workers. The frequencies of alleles related to risk were higher in the CF group for GSTM1, GSTT1, CYP2E1 7632T > A, but lower for NQO1 and CYP2E1 1053C > T polymorphisms. The MPO variant allele showed no difference. Except for GSTM1 and CYP2E1 1053C > T, the allele frequencies were similar to the findings of most other studies [43-50]. Chen et al. (2007) [28] investigated the relationship between the same polymorphisms and BP in workers exposed to benzene, and they found an association with NQO1 and GSTT1, but not with CYP2E1, GSTM1, and MPO. Study of Wan et al. (2002) [22] also found association between GSTT1 null genotype and significant increase in risk of BP, however the studies of Sun et al. (2008) [51] and Lanet al. (2004) [4] reported no association. We did not observe association between clinical findings related to BP and NQO1, MPO, CYP2E1 and GSTT1 polymorphisms, but we found an association with GSTM1.

The literature also has reported the influence of gene-gene interaction on benzene toxicity. Several studies have shown that combinations of high CYP2E1 and MPO activities and low or negligible NQO1, GSTM1 and GSTT1 activities (high bioactivation combined with low detoxification), may increase the risk of benzene-induced toxicity [12,28,32,52-56]. We observed an association between subjects carrying more alleles related to risk and clinical changes related to benzene poisoning, which may suggest that interactions of multi-genes in benzene metabolism may contribute to the development of these changes.

In conclusion, our findings suggest that the GSTM1 null genotype may play a role in the development of clinical alterations related to BP. However, further studies with larger sample sizes will be needed to confirm these findings. Although the literature data on genetic susceptibility to BP have so far been inconclusive, it is generally accepted that variations in benzene metabolizing genes may modify benzene toxicity and should be taken into consideration when carrying out risk assessments for exposed workers.

\section{Acknowledgments}

The authors thank Sinpospetro Union for their collaboration with the gas-station attendants. This study was supported by CNPq, FAPERJ and Oswaldo Cruz Foundation.

\section{Author Contributions}

Simone Mitri performed genetic analysis; Marianne Medeiros Tabalipa and Ubirani Barros Otero conducted clinical analysis; Antônio Sérgio Almeida Fonseca interpreted clinical outcomes; Josino Costa Moreira and Paula de Novaes Sarcinelli participated in the conception and coordination of the study. All authors discussed the final version of the manuscript and approved it. 


\section{Conflicts of Interest}

The authors declare no conflict of interests.

\section{References}

1. Mendes, R. Benzenism: subsidy for identifying occupational groups subject to higher risk of exposure. Boll. da SBHH 1987, 144, 135-151. (In Portuguese)

2. Augusto, L.G.S. Estudo longitudinal e morfológico (medula óssea) em pacientes com neutropenia secundária à exposição ocupacional crônica ao benzeno. Dissertação de mestrado, Universidade Estadual de Campinas (UNICAMP), Campinas, Brazil, 1991.

3. Snyder, R. Overview of the toxicology of benzene. J. Toxicol. Environ. Health Amer. 2000, 61, $5-6$.

4. Lan, Q.; Zhang, L.; Li, G.; Vermeulen, R.; Weinberg, R.S.; Dosemeci, M.; Rappaport, S.M.; Shen, M.; Alter, B.P.; Wu, Y.; Kopp, W.; Waidyanatha, S.; Rabkin C.; Guo, W.; Chanock, S.; Hayes, R.B.; Linet, M.; Kim, S.; Yin, S.; Rothman, N.; Smith, M.T. Hematotoxicity in workers exposed to low levels of benzene. Science 2004, 306, 1774-1776.

5. Rappaport, S.M.; Kim, S.; Lan, Q.; Li, G.; Vermeulen, R.; Waidyanatha, S.; Zhang, L.; Yin, S.; Smith, M.T.; Rothman N. Human benzene metabolism following occupational and environmental Exposures. Chem. Biol. Interact. 2010, 184, 189-195.

6. McHale, C.M.; Smith, M.T.; Zhang, L. Application of toxicogenomic profiling to evaluate effects of benzene and formaldehyde: From yeast to human. Ann. N.Y. Acad. Sci. 2014, 1310, 74-83.

7. Krieg, J.E.F.; Mathias, P.I.; Toennis, C.A.; Clark, J.C.; Marlow, K.L.; B'hymer, C.; Singh' N.P.; Gibson, R.L.; Butler, M.A.. Detection of DNA damage in workers exposed to JP-8 jet fuel. Mutat. Res. 2012, 747, 218-227.

8. Coutrim, M.X.; Carvalho, L.R.F.; Arcuri, A.S.A. Avaliação dos Métodos analíticos para a determinação de metabólitos do benzeno como potenciais biomarcadores de exposição humana ao benzeno no ar. Quím. Nova 2000, 23, 653-663.

9. Lin, Y.S.; Vermeulen, R.; Tsai, C.H.; Waidyanatha, S.; Lan, Q.; Rothman, N.; Smith, M.T.; Zhang, L.; Shen, M.; Li, G.; Yin, S.; Kim, S.; Rappaport, S.M. Albumin adducts of electrophilic benzene metabolites in benzene-exposed and control workers. Environ. Health Perspect. 2007, $115,28-34$.

10. Steinmaus, C.; Smith, A.H.; Jones, R.M.; Smith, M.T. Meta-analysis of benzene exposure and non-Hodgkin lymphoma: Biases could mask an important association. Occup. Environ. Med. 2008, 65, 371-378.

11. Smith, M.T. Advances in Understanding Benzene Health Effects and Susceptibility. Annu. Rev. Public Health 2010, 31, 133-148.

12. Carrieri, M.; Bonfiglio, E.; Escapellato, M.L.; Maccà, I.; Tranfo, G.; Faranda, P.; Paci, E.; Bartolucci, G.B. Comparison of exposure assessment methods in occupational exposure to benzene in gasolina filling-station attendants. Toxicol. Lett. 2006, 162, 146-152. 
13. Kim, Y.J.; Choi, J.Y.; Paek, D.; Chung, H.W. Association of the NQO1, MPO, and XRCC1 polymorphisms and chromosome damage among workers at a petroleum refinery. J. Toxicol. Environ. Health Amer. 2008, 71, 333-341.

14. Moura-Correa, M.J.; Jacobina, A.J.R.; Santos, A.S.; Pinheiro, R.D.C.; Menezes, M.A.C.; Tavares, A.M.; Pinto, N.F. Benzene exposure of workers of Petrol Stations in Brazil. Ciência. Saúde Coletiva 2014, 19, 4637-4648. (In Portuguese)

15. Ruiz, M.A. O problema da leucopenia em Cubatão. Bol. Soc. Bras. Hematol. Hemoter. 1985, 7 , 171-172.

16. Ruiz,M.A.; Vassallo, J.; Souza, C.A. Alterações hematológicas em pacientes expostos cronicamente ao benzeno. Rev. Saúde Pública 1993, 27, 145-151.

17. Ministério da Saúde. Chemical Risk: Attention to the Health of Workers Exposed to Benzene. Workers Health Protocols Series A; Secretaria de Atenção à Saúde Departamento de Ações Programáticas Estratégicas: Brasília, Brazil, 2006. (In Portuguese)

18. Ross, D. The role of metabolism and specific metabolites in benzene-induced toxicity: Evidenceand issues. J. Toxicol. Environ. Health Amer. 2000, 6, 357-372.

19. Snyder, R. Xenobiotic metabolism and the mechanism(s) of benzene toxicity. Drug Metab. Rev. 2004, 36, 531-547.

20. Zhang, G.H.; Ye, L.L.; Wang, J.W.; Ren, J.C.; Xu, X.W.; Feng, N.N.; Zhou, L.F.; Ru, J.G.; Hao' Y.H.; Tian, W.; Sun, P.; Au, W.W.; Christiani, D.C.; Xia, Z.L. Effect of polymorphic metabolizing genes on micronucleus frequencies among benzene-exposed shoe workers in China. Int. J. Hyg. Environ. Health 2014, 217, 726-732.

21. Rothman, N.; Smith, M.T.; Hayes, R.B.; Traver, R.D.; Hoener, B.; Campleman, S.; Li, G.L.; Dosemeci, M.; Linet, M.; Zhang, L.; Xi, L.; Wachol4der, S.; Lu, W.; Meyer, K.B.; Holland, N.T.; Stewart, J.T.; Yin, S.; Ross, D. Benzene poisoning, a risk factor for hematological malignancy, is associated with the NQO1 $609 \mathrm{C} \rightarrow \mathrm{T}$ mutation and rapid fractional excretion of chlorzoxazone. Cancer Res. 1997, 57, 2839-2842.

22. Wan, J.; Shi, J.; Hui, L.; Wu, D.; Jin, X.; Zhao, N.; Huang, W.; Xia, Z. Association of genetic polymorphisms in CYP2E1, MPO, NQO1, GSTM1, and GSTT1 genes with benzene poisoning. Environ. Health Perspect. 2002, 110, 1213-1218.

23. Carrieri, M.; Bartolucci, G.B.; Scapellato, M.L.; Spatari, G.; Sapienza, D.; Soleo, L. Influence of glutathione S-transferases polymorphisms on biological monitoring of exposure to low doses of benzene. Toxicol. Lett. 2012, 213, 63-68.

24. Kelly, R.S.; Vineis, P. Biomarkers of susceptibility to chemical carcinogens: The example of non-Hodgkin lymphomas. Bras. Med. Bull. 2014, 111, 89-100.

25. Rossi, A.M.; Guarnieri, C.; Rovesti, S.; Gobba, F.; Ghittori, S.; Vivoli, G.; Barale, R. Genetic polymorphisms influence variability in benzene metabolism in humans. Pharmacogenetics 1999, 9, 445-451.

26. Pavanello, S.; Clonfero, E. Biological indicators of genotoxic risk and metabolic polymorphisms. Mutat. Res. 2000, 463, 285-308. 
27. Kim, S.; Lan, Q.; Waidyanatha, S.; Chanock, S.; Johnson, B.A.; Vermeulen, R.; Smith, M.T.; Zhang, L.; Li, G.; Shen, M.; Yin, S.; Rothman, N.; Rappaport, S.M. Genetic polymorphisms and benzene metabolism in humans exposed to a wide Range of air concentrations. Pharmacogenet. Genomics 2007, 17, 789-801.

28. Chen, Y.; Li, G.; Yin, S.; Xu, J.; Ji, Z.; Xiu, X.; Liu, L. Genetic polymorphisms involved in toxicant-metabolizing enzymes and the risk of chronic benzene poisoning in Chinese occupationally exposed populations. Xenobiotica 2007, 37, 103-112.

29. Dougherty, D.; Garte, S.; Barshowsky, A.; Zmuda, J.; Taioli, E. NQO1, MPO, CYP2E1, GSTT1 and GSTM1 polymorphisms and biological effects of benzene exposure: A literature review. Toxicol. Lett. 2008, 182, 7-17.

30. Hoet, P.; De Smedt, E.; Ferrari, M.; Imbriani, M.; Maestri, L.; Negri, S.; De Wilde, P.; Lison, D.; Haufroid, V. Evaluation of urinary biomarkers of exposure to benzene: Correlation with blood benzene and influence of confounding factors. Int. Arch. Occup. Environ. Health 2009, 82, 985-995.

31. Neafsey, P.; Ginsberg, G.; Hattis, D.; Johns, D.O.; Guyton, K.Z.; Sonawane, B. Genetic polymorphism in CYP2E1: Population distribution of CYP2E1 activity. J. Toxicol. Environ. Health B. Crit. Rev. 2009, 12, 362-388.

32. Manini, P.; De Palma, G.; Andreoli, R.; Mozzoni, P.; Poli, D.; Goldoni, M.; Petyx, M.; Apostoli, P.; Mutti, A. Occupational exposure to low levels of benzene: Biomarkers of exposure and nucleic acid oxidation and their modulation by polymorphic xenobiotic metabolizing enzymes. Toxicol. Lett. 2010, 193, 229-235.

33. Piccoli, P.; Carrieri, M.; Padovano, L.; Di Mare, M.; Bartolucci, G.B.; Fracasso, M.E.; Lepera, J.S.; Manno, M. In vivo CYP2E1 phenotyping as a new potential biomarker of occupational and experimental exposure to benzene. Toxicol. Lett. 2010, 192, 29-33.

34. Hollins, D.M.; Kerger, B.D.; Unice, K.M.; Knutsen, J.S.; Madl, A.K.; Sahmel, J.E.; Paustenbach, D.J. Airborne benzene exposures from cleaning metal surfaces with small volumes of petroleum solvents. Int. J. Hyg. Environ. Health 2013, 216, 324-332.

35. Arcuri, A.; Costa, D.; Machado, J.; Cardoso, L.; Magrini, R.; Marra, V. Surveillance of the Chemical Risk of Benzene; Secretaria de Atenção à Saúde Departamento de Ações Programáticas Estratégicas: Brasília, Brazil, 2005. (In Portuguese)

36. Navasumrit, P.; Chanvaivit, S.; Intarasunanont, P.; Arayasiri, M.; Lauhareungpanya, N.; Parnlob, V.; Settachan, D.; Ruchirawat, M. Environmental and occupational exposure to benzene in Thailand. Chem. Biol. Interact. 2005, 153-154, 75-83.

37. Weisel, C.P. Benzene exposure: An overview of monitoring methods and their findings. Chem. Biol. Interact. 2010, 184, 58-66.

38. D’Alascio, R.G.; Menegali, M.; Bornelli, A.S.; Magajewski, F. Sintomas relacionados à exposição ocupacional ao benzeno e hábitos ocupacionais em trabalhadores de postos de revenda de combustíveis a varejo na região sul de Santa Catarina. Rev. Bras. Med. Trab. 2014, 12, 21-29.

39. Ruiz, M.A. Alterações hematológicas do benzenismo. Bol. Soc. Bras. Hematol. Hemoter. 1987, 9 , 129-134. 
40. Ruiz, M.A.; Augusto, L.G.; Vassallo, J.; Vigorito, A.C.; Lorand-Metze, I.; Souza, C.A. Bone marrow morphology in patients with neutropenia due to chronic exposure to organic solvents (benzene): Early lesions. Pathol. Res. Pract. 1994, 190, 151-154.

41. De Palma, G.; Manno, M. Metabolic polymorphisms and biomarkers of effect in the biomonitoring of occupational exposure to low-levels of benzene: State of the art. Toxicol. Lett. 2014, 231, 194-204.

42. Qu, Q.; Shore, R.; Li, G.; Jin, X.; Chen, L.C.; Cohen, B.; Melikian, A.A.; Eastmond, D.; Rappaport, S.M.; Yin, S.; Li, H.; Waidyanatha, S.; Li, Y.; Mu, R.; Zhang, X.; Li K. Hematological changes among Chinese workers with a broad range of benzene exposures. Amer. J. Ind. Med. 2002, 42, 275-285.

43. Gattás, G.J.; Soares-Vieira, J.A. Cytochrome P450-2E1 and glutathione S-transferase mu polymorphisms among Caucasians and mulattoes from Brazil. Occup. Med. 2000, 50, 508-511.

44. Rossini, A.; Rapozo, D.C.M.; Amorim, L.M.F.; Macedo, J.M.B.; Medina, R.; Neto, J.F.N.; Gallo, C.V.M.; Pinto, L.F.R. Frequencies of GSTM1, GSTT1, and GSTP1 polymorphisms in a Brazilian population. Genet. Mol. Res. 2002, 3, 233-240.

45. Canalle, R.; Burim, R.V.; Tone, L.G.; Takahashi, C.S. Genetic polymorphisms and susceptibility to childhood acute lymphoblastic leukemia. Environ. Mol. Mutagen. 2004, 4, 100-109.

46. Rossini, A.; Lima, S.S.; Rapozo, D.C.M.; Faria, M.; Albano, R.M.; Pinto, L.R.F. CYP2A6 and CYP2E1 polymorphisms in a Brazilian population living in Rio de Janeiro. Braz. J. Med. Biol. Res. 2006, 39, 195-201.

47. Maciel, M.E.; Oliveira, F.K.; Propst, G.B.; Bicalho, M.G.; Cavalli, I.J.; Ribeiro, E.M.S.F. Population analysis of xenobiotic metabolizing genes in South Brazilian Euro and Afro-descendants. Genet. Mol. Biol. 2009, 32, 723-728.

48. Silva, J.; Moraes, C.R.; Heuser, V.D.; Andrade, V.M.; Silva, F.R.; Kvitko, K.; Emmel, V.; Rohr, P.; Bordin, D.L.; Andreazza, A.C.; Salvador, M.; Henriques, J.A.P.; Erdtmann, B. Evaluation of genetic damage in a Brazilian population occupationally exposed to pesticides and its correlation with polymorphisms in metabolizing genes. Mutagenesis 2008, 23, 415-422.

49. Silveira, V.S.; Canalle, R.; Scrideli, C.A.; Queiroz, R.G.; Tone, L.G. Role of the CYP2D6, EPHX1, MPO, and NQO1 genes in the susceptibility to acute lymphoblastic leukemia in Brazilian children. Environ. Mol. Mutagen. 2010, 51, 48-56.

50. Pinheiro, D.S.; Rocha Filho C.R.; Mundim, C.A.; Júnior, P.M.; Ulhoa, C.J.; Reis, A.A.; Ghedini, P.C. Evaluation of glutathione S-transferase GSTM1 and GSTT1 deletion polymorphisms on type-2 diabetes mellitus risk. PLOS ONE 2013, 8, e76262.

51. Sun, P.; Qian, J.; Zhang, Z.B.; Wan, J.X.; Wu, F.; Jin, X.P.; Fan, W.W.; Lu, D.R.; Zhao, N.Q.; Christiani, D.C.; Xia, Z.L. Polymorphisms in phase I and phase II metabolism genes and risk of chronic benzene poisoning in a Chinese occupational population. Carcinogenesis 2008, 29, 2325-2329.

52. Sørensen, M.; Poole, J.; Autrup, H.; Muzyka, V.; Jensen, A.; Loft, S.; Knudsen, L.E. Benzene exposure assessed by metabolite excretion in Estonian oil shale mineworkers: Influence of glutathione s-transferase polymorphisms. Cancer Epidem. Biomarker Prev. 2004, 13, 1729-1735.

53. Johnson, E.S.; Langard, S.; Lin, Y.S. A critique of benzene exposure in the general population. Sci. Total Environ. 2007, 374, 183-198. 
54. Angelini, S.; Kumar, R.; Bermejo, J.L.; Maffei, F.; Barbieri, A.; Graziosi, F.; Carbone, F.; Cantelli-Forti, G.; Violante, F.S.; Hemminki, K.; Hrelia, P. Exposure to low environmental levels of benzene: Evaluation of micronucleus frequencies and S-phenylmercapturic acid excretion in relation to polymorphisms in genes encoding metabolic enzymes. Mutat. Res. 2011, 719, 7-13.

55. Mansi, A.; Bruni, R.; Capone, P.; Paci, E.; Pigini, D.; Simeoni, C.; Gnerre, R.; Papacchini, M.; Tranfo, G. Low occupational exposure to benzene in a petrochemical plant: Modulating effect of genetic polymorphisms and smoking habit on the urinary t, t-MA/SPMA ratio. Toxicollett 2012, 213, 57-62.

56. Carbonari, D.; Proietto, A.; Fioretti, M.; Tranfo, G.; Paci, E.; Papacchini, M.; Mansi, A. Influence of genetic polymorphism on t, t-MA/S-PMA ratio in 301 benzene exposed subjects. Toxicol. Lett. 2014, 231, 205-212.

(C) 2015 by the authors; licensee MDPI, Basel, Switzerland. This article is an open access article distributed under the terms and conditions of the Creative Commons Attribution license (http://creativecommons.org/licenses/by/4.0/). 